\title{
Digterskap en poëtikale besinning by vier Franse Simboliste
}

\begin{abstract}
When one studies the influence of French Symbolism on contemporary Westen poetry it is necessary to define both Symbolism and influence. The first tern is problematic not only because it is difficult to delimitate the reality it designates but because of the nature of the movement itself. Rather than defining from the outside we will ty to understand the genesis of the work of the four great 'symbolist' poets in France, namely Nerval, Baudelaire, Rimbaud, and Mallarmé. We do not consider the notion of influcnce as causal but as a confrontation from one poet's work with that of another, the presence of poets of the past in the thinking of later poets. The structural genesis of the poetics of the four poets shows a marked resemblance in as far as they all overestimate the creative capabilities of imagination and language. Their poety is not so much a meditation about the essence of poetry as an internogation about its power to change reality. Modern poetry develops thus inside a tension between dream ano action, but it is only now, in the work of the most lucid contenporan' poets, and after the sometimes draconian claims of theory in the human sciences, that attention has focused on a possible solution of poetry's dilemma which was already present in the French poet's work: this solution can be indicated with the word caritas in the strong sense of the word namety the acceplation of coningency, the need of incanation and the pursuit of universality through poctic language.
\end{abstract}

\section{Inleidend}

In hierdie artikel word 'n oorsig gegee van die eiesoortigheid van die digterskap van Nerval, Baudelaire, Rimbaud en Mallarmé - vier Franse Simboliste. Die verband tussen hul lewe en digterlike aktiwiteit, asook die aard van die kritiese besinning oor hul werk word in die bespreking aangeraak. Hierdie benaderingswyse poog egter nie om alle fasette van die Simbolisme as beweging te betrek nie. Die mikpunt is eerder om te probeer deurdring tot die kern van die digkuns soos dit ontwikkel het sedert die middel van die $19 \mathrm{de}$ eeu. Eén ding staan inderdaad vas: die hedendaagse digters voel hulleself nog fundamenteel verbonde aan die werk van sommige Franse digters wat teen ongeveer 1850 geskryf of begin skryf het. Ons lewe eintlik nog binne die simbolistiese periode. Selfs die huidige modeteorieë in die poëtiek spruit voort uit daardie digters se kritiese nadenke oor hulle eie aktiwiteit.

Die vier Franse digters wat aan die oorsprong van die 'simbolistiese' beweging staan maar terselfdertyd ook die moderne digkuns in sy ontwikkeling beheers is Nerval, Baudelaire, Rimbaud en Mallarmé, omdat hulle werk 'n radikale vraagstelling oor die wese en funksie van die digkuns verteenwoordig. Om egter werklik insig te verkry in die eietydse poësie in 
Wes-Europa moet die werk van Friedrich Hoelderlin ook by dié kwartet gevoeg word. Hy het egter al ongeveer 'n halwe eeu voor die begin van die Simbolisme opgehou om te skryf en het eers aan die begin van die twintigste eeu weer op die voorgrond getree vanweë die navorsing van Hellingrath wat weer 'n groot invloed gehad het op die kring rondom Stefan George. Dit is egter eers Heidegger se interpretasie van Hoelderlin se werk - weer eens ten opsigte van die wese van digkuns - wat Hoelderlin se inspirerende aanwesigheid in die hedendaagse digkuns merkbaar gemaak het.

\section{Invloed}

'Invloed' kan slegs betekenis hê as dit verstaan word as 'n kreatiewe blootstelling van een digter se aktiwiteit met 'n ander digter se werk, buite elke kousale verband. Invloed beskou ek as 'n proses van blootstelling: die omgang van 'n digter met die werk van ander digters skep helderheid oor die sin van die digter se eie digkuns. Dit moet onmiddellik daaraan toegevoeg word dat ek 'n digter se werk nie los sien van sy lotsbestemming nie, juis omdat die digwerk vir hom 'n manier is om sy eie lewe te verstaan en om daaraan gestalte te gee. Weer eens gaan dit nie om 'n vermeende kousale verband tussen gebeurtenisse in die lewe van die digter en sy gepubliseerde tekste nie. Van belang is die ontstaan van die werk, die skeppende en vormende omgang met die eie lewe, 'n omgang wat vir 'n digter nie anders as in en deur die taal gestalte kan kry nie. In die volgende uiteensetting sal hierdie siening van die genetiese struktuur van 'n werk hopelik duideliker word. Ek wil ook onmiddellik daarop wys dat ek struktuur nie sien as 'n statiese sisteem nie maar as 'n konfigurasie. as 'n wording van 'n sinvolle geheel.'

\section{Simbolisme}

Die probleem met die benaming Simbolisme bestaan nie alleen daarin dat daar so baie verskillende definisies daarvan gegee is nie, maar ook dat daar binne een definisie 'n groot verskeidenheid eienskappe daaraan toegeken word. ${ }^{2}$ Die rede daarvoor is waarskynlik die feit dat genoemde digters radikaal was in hulle soektog na die wortels van hulle eie aktiwiteit en so $n$ soeke kan daarom moeilik tot een periode beperk word. Dit sal meer sinvol wees om te vra warom hierdie radikale soeke juis teen ongeveer die middel van die 19de eeu plaasgevind het.

In 'n eerste benadering kan gestel word dat een van die mees algemeen aanvaarde gemeenskaplike kenmerke van genoemde vier digters is dat hulle werk weer aansluit by die tradisie van simboliese denke. In dié sin is daar egter niks nuuts in die werk van Nerval of Baudelaire nie. Wat egter wel opvallend is, is die feit dat die terugkeer na die tradisionele simboliese denke saamval met die moment waarop die funksionalistiese denke sy eerste triomf vier in die tegnologie. Die radikaliteit van Nerval, Baudelaire, Rimbaud en Mallarmé se denke lê daarin dat hulle reageer op 'n fundamentele verandering in die houding van die mens teenoor die wêreld waarin hy lewe. In die simboliese denke gaan dit veral daarom om die mens met die kosmos te versoen, om die verlore eenheid te herstel.

\footnotetext{
${ }^{1}$ Vir 'n filosofiesc begronding van die genetiese struktuurbegrip verwys ek na die werk van die Duitse filosoof Hcinrich Rombach (1971).

${ }^{2}$ Die probleme met 'n definisie van die Simbolisme word treffend uiteengesit deur Wellek (1970).
} 
Die simboliese denke berus dus op 'n substansialistiese ontologie. Dit word egter in die moderne tyd vervang deur 'n funksionalistiese ontologie: binne die raamwerk hiervan begin die mens in te gryp in die wêreld omdat hy nou 'n standpunt teenoor en buite die wêreld inneem. omdat hy objektief daarteenoor gaan staan. ${ }^{3}$ Daardeur verloor die simbole nie alleen hulle waarde in die gemeenskap nie, maar selfs die ervaarbare, direk waarneembare aspekte van die natuur soos kleur en vorm, die grein van dinge soos dit in die aktuele ervaringsproses aanwesig is, verdwyn ten gunste van meet- en weegbaarheid. Daar is dan geen ooreenstemming meer tussen gees en aarde nie, of beter gestel, die moontlike ooreenstemming (Baudelaire noem dit correspondance) is nou slegs 'n herinnering. Een van die gevolge is dat die simboliese proses nou nie meer 'n buiteruimte het waarin dit kan ontplooi nie, dat die verbeeldingskrag nou nie meer aan die werk is binne die raamwerk van die universum nie, dat die eenheid tussen mens en kosmos verbreek is. Saamwees het nou onmoontlik geword, met die gevolg dat die verbeelding homself nou nog net binne die mens self, in dit wat die onderbewuste genoem word, kan uitleef. 'n Verdere gevolg is dat die digkuns hermeties geword het omdat dit nou na die voorskrif van die onderbewuste luister en die verwoording van hersenskimme as die enigste moontlikheid sien. Dit is 'n gevaarlike toestand, want die verhouding van die mens met die werklikheid word nog steeds gedeeltelik bepaal deur verlange. Die wetenskap lê daardie verlange die stilswye op, met die gevolg dat die digter nie anders kan nie as om homself op te sluit in eensaamheid en in opstandigheid.

Om tot die kern van die huidige digkuns te kan deurdring, mag dit nuttig wees om: $n$ onderskeid te tref tussen dit wat ek die simboliese noem, en die simbolistiese. Die simbolistiese geesteshouding is die toegespitste, byna sieklike vorm van die simboliese: sieklik omdat siekte juis 'n reaksieverskynsel is teen dit wat die lewe bedreig; net so is digkuns 'n reaksie teen dit wat die mensheid bedreig. Die simbolistiese skool het slegs die formele kenmerke van die vier groot digters oorgeneem sonder om die diepe noodsaakiikheid daarvan te begryp. Daarom moet ons eers gaan kyk na en probeer deurdring tot die genese (in die sin van wording) van hulle digkuns. Met hierdie benaderingswyse sal dit terselfdertyd ook duidelik word dat Nerval en Baudelaire alreeds 'n weg gevind het om vir die verlies van die simboliese te kompenseer, terwyl Rimbaud en Mallarmé verstrik geraak het in die aporie van absolute digkuns. Dit het gebeur omdat Rimbaud en Mallarmé die ou substansie vervang het met 'n sisteem en van die digkuns 'n effek in 'n funksionalistiese sin verlang het - 'n effek wat die woord as sodanig nie kan oplewer nie. Hierdie stelling is egter nie 'n oordeel nie en nog minder 'n vonnis: omdat Rimbaud en Mallarmé hulle eie siening deeglik deurdink het, het hulle vir die volgende generasies digters 'n pad oopgemaak al het hulle eie poging in 'n doodloopstraat geëindig. Dit moet ook gestel word dat altwee hulle lewe aan die saak van die digkuns gewy het.

${ }^{3}$ Die verskil tussen substansialistiese en funksionalistiese ontologie word bespreek deur Rombach (1981). 


\section{Genese van digwerk}

Ons moet allereers probeer om die genese van digwerk te begryp. ${ }^{4}$ Die genetiese moment waarna ons soek, is die wyse waarop hulle digwerk, in die sin van arbeid aan 'n woordwêreld, eksistensieel van belang was vir elkeen van die vier genoemde digters. Anders uitgedruk: wat is die plek wat skryf ingeneem het in die wyse waarop hulle aan hulle eie lewe vorm en betekenis gegee het? Daar moet onmiddellik opgemerk word dat 'n digter nie 'n uitsonderlike mens is nie, maar dat hy wel menswording intenser belewe. Dat hierdie menswording vir die digter sy beslag in taal kry, maak nie van hom 'n uitsondering nie: taal is immers 'n middel tot menswording, sowel filogeneties as ontogeneties: die persoon word én skep homself ook terselfdertyd in en deur taal. Ons lewende liggaam is taal. Wat egter aan die digters se werk eie is, is die feit dat hulle ' $n$ problematiese verhouding met taal gehad het, moontlik as gevolg van gebeurtenisse in hulle kinderjare.

Die wesensverband tussen taal en liggaam is konkreet in dié sin dat die mens sy eie liggaam van ' $n$ ander liggaam kry; hy deel eers ' $n$ liggaam met sy moeder en by geboorte word hy daarvan geskei. By geboorte vind daar 'n onherstelbare breuk plaas, 'n eenheid word verbreek. Dié breuk kan later simbolies herstel word, maar vir die mens beteken dit dat sy verlange veral gerig is op die herstel van eenheid, gerig is op ontmoeting met ander. Daarom is die band met die moeder, die liggaamlike band, van so 'n groot belang. Hierdie band word by geboorte verbreek en dit kan eers weer herstel word deur tekens: glimlag, skreeu, liefkosing en taal. Die term moedertaal kry dus 'n wesenlike betekenis: saam met sy liggaam kry die mens ook taal van sy moeder. Taal is sodoende 'n dubbele werklikheid: die noodsaak om taal te gebruik, beteken enersyds dat die eenheid verbreek is; andersyds is taal egter die enigste manier om daardie eenheid te herstel.

As ons dan kyk na die kinderjare van dié vier digters, sal ons vasstel dat al vier 'n problematiese verhouding met hulle moeder gehad het: vir al vier was die moeder onbereikbaar. Nerval het sy moeder verloor toe hy twee jaar oud was. Baudelaire het, na die dood van sy natuurlike vader, byna twee jaar lank in 'n intieme verhouding met sy moeder gelewe totdat haar hertroue 'n brutale einde gemaak het aan dié paradyslike toestand. Rimbaud se vader het sy familie in die steek gelaat toe die digter ses jaar oud was. Sy moeder het toe die rol van vader oorgeneem en haar kinders (veral haar twee seuns) onnodig streng en koud behandel. In die laaste twee gevalle het die moeders ook duidelik laat blyk dat hulle verhouding met hulle seuns bepaal is deur 'n ideële beeld eerder as deur liefde en geneentheid vir die kind soos hy werklik is. Mallarmé se moeder het gesterf toe hy vyf jaar oud was en vyf jaar later het sy vader hertrou. Mallarmé het die grootste gedeelte van sy jeug in koshuise deurgebring en aanvanklik van sy suster 'n moederfiguur gemaak. Hierdie suster het gesterf toe hy vyftien jaar oud was, midde in die puberteitsperiode. In al vier gevalle het die moeder dus ontbreek of onbereikbaar of ongenaakbaar geword. Hiermee word nie beweer dat daar 'n kousale verband is tussen die gemis aan 'n moederfiguur en digterlike roeping nie; die feit is eerder dat die genese van hulle digwerk gedeeltelik dinamies gestruktureer is deur daardie moederlose toestand. Om die belang daarvan in te sien, wys ek weer op die feit dat die kind sy moeder se liggaam

\footnotetext{
4 Baudelaire se briewe word aangehaal uit die uitgawe van die Pléiade, aangedui met B,Cor en bladsynommer. Mallarmé se briewe, vir sover nodig, is volgens die uitgawe deur Gallimard.
} 
deel. Na geboorte egter, gedurende sy kinderjare, moet die kind alleen probeer regkom. moet hy sy eie liggaan leer ken en gebruik en gedurende dieselfde periode moet hy leer praat. Om te praat is ' $n$ simboliese handeling wat skeppend werksaam is in die individuasieproses. In die begin is woorde nog simbole in die ware sin van die woord: woorde stel nog 'n eenheid met dinge en persone daar en dit is slegs na 'n lang oorgangsperiode dat die kind die grense van sy eie individualiteit leer ken.

In die begin is die aanleer van taal essensieel naamgewing, maar vroeër of later moet die kind vasstel dat daar tog 'n onoorbrugbare kloof is tussen woord en ding. Die enigste persoon wat die vertroue in die taal (nie die magie daarvan nie, maar wel sy inkarnatiewe krag, sy simboliese funksie) kan herstel, is die moeder wat terselfdertyd die grense daarvan kan laat ervaar, nie as beperkings nie, nie as suiwer negatief omdat taaltekens die mens in 'n onontkombare eensaamheid sou opsluit nie, maar as transisionele ruimte 5 warin moontlikhede en virtuele verbande verken kan word as 'n speelruimte waarin die eenheid met die ander tog weer ingeoefen kan word.

In die geval van die vier digters was die moeders nie daar om dit te doen nie of hulle het Jeur die feit dat hulle in die plek van die kind ' $n$ ideële en terselfdertyd ' $n$ ideale beeld gestel het, hulle seuns tot eensaamheid verdoem. Gevolglik het die kind aan die taal en aan die verbeeldingswêreld 'n oordrewe belang toegeken, dit selfs verabsoluteer. Die band met die ander word sodoende ingeoefen, nie in 'n transisionele ruimte waarin ontmoeting moontlik word nie, maar in 'n oniriese ruimte. die ruimte van die droom. Maar om die droom te koester, beteken ook om daadwerklik aksie en effektiewe ontmoeting onmoontlik te maak. Die geskiedenis van die digkuns ná Baudelaire sou inderdaad na sy ontstaan en. ontwikkeling verstaan kan word as die vormgewing aan 'n spanningsveld wat droom en aksie onoorbrugbaar van mekaar skei. As Baudelaire (1951:189) in "Le reniement de Saint Pierre" sê:

Certes, je sortirai, quant à moi, satisfait

D'un monde ou l'action n'est pas la socur du réve

dan verwoord hy eintlik 'n soort program vir die toekomstige digkuns. Hoewel Baudelaire self nog die kontradiksie in sy eie lewe verdra het, het 'n Mallarmé hom baie skerp veroordeel omdat hy nie die suiwer droom gekies het nie en Rimbaud het hom verwyt dat hy nog te diep in die droom opgesluit was, aangesien hy te veel waarde aan die vorm van sy gedigte geheg het.

Dit is egter nog nie die belangrikste nie: al vier digters het op een of ander manier tog agtergekom dat om in die droom te lewe, tot gevolg het dat mens in totale isolasie lewe en hulle het ook die insig verkry dat die sleutel tot die oplossing in naasteliefde lê. Die vraag wat dus in die simbolistiese digkuns gestel word, gaan nie oor die wese van die digkuns nie maar wel oor wat die digkuns vermag. Hierdie vraag kan slegs gestel word en beter belig word as ons die werk van Nerval, Baudelaire, Rimbaud en Mallarmé en hulle poëtiek ondersoek. Dié ondersoek sal duidelik maak in hoeverre die latere Simboliste, die surrealiste, lettriste en hedendaagse tekstualiste slegs gedeeltelik die innerlike noodsaak van daardie simboliese poëtiek ingesien het en slegs bepaalde aspekte daarvan gekies het wat met hulle eie bekommernisse of drome ooreengestem het.

\footnotetext{
${ }^{5}$ Die begrip transisionele nimte kom van Winnicot af. Hy bedocl daarmec dic speclruimte waarin in kind die grense van sy eie liggaam leer ken, binne die ruimte waarin sy moeder se liggaam en objekte ook 'n plek het. Kyk Winnicot (1971).
} 


\section{Poētiek en lotsbestemming}

Dit mag nou al duidelik wees dat die poëtiek van 'n digter nie losgemaak kan word van die rol wat skryf speel in die belewenis van sy eie lotsbestemming nie. Ek gaan uit van die standpunt dat digterlike roeping en persoonlike lotsbestemming één is: om te skrywe is 'n manier om aan die lewe sin en betekenis te gee, om daardie betekenis te verwoord, en om dit in die konkrete lewe op die proef te stel. Daar waar die digter vroeër miskien die persoon was om die versugtinge van die gemeenskap, sy vrees en hoop te verwoord, is dit nou so dat die digter in sy eie lewe en lot as skrywer 'n soort offer bring. Hy is nie spreekbuis of woordvoerder wat bestaande waardes en norme verwoord nie. Wat in die skeppingsproses gebeur, hoe digkuns aan 'n lewe vorm kan gee, wat die vermoë van poëtiese taalgebruik is, dit is die vrae wat sedert die middel van die 19de eeu in die digkuns gestel word. Dit is nie so, soos so dikwels beweer word, dat die digkuns sedert daardie tyd op soek is na sy eie wese en daarom suiwer refleksief sou wees, 'n spel met woorde ter wille van woorde self nie. Die digkuns is 'n vraag oor die waarde van taal in die soektog na eenheid, 'n vraag oor die effektiwiteit van taal in 'n poging om mense in die universele te laat saam wees. In die bespreking van die vier digters en hulle poëtiek in die genetiese sin van die woord, neem ek telkens as vertrekpunt 'n teks wat outobiografies is vir sover dit die rol van skrywe in die bestaan van die digter belig.

\subsection{Nerval}

As vertrekpunt neem ek die laaste teks wat Nerval geskryf het, "Aurélia", 'n verhaal wat sy vriende Theophile Gautier en Arsêne Houssaye postuum in die Revue des deux mondes gepubliseer het (Nerval, 1974:357-425). Nerval self het in die laaste sin van die teks 'n kardinale waarde aan die outobiografiese in die teks toegeken as hy sẻ dat die ervaring wat in die verhaal verhelder word, vir hom neergekom het op 'n inisiasieproses (Nerval, 1974:414). In "Aurélia" berig Nerval oor sy poging om sy eie lewensprobleem op te los deur stelselmatig die droom met die werklikheid te meng. Hy het sy geliefde verloor en hy is weens treffende ooreenkomste tussen gebeurtenisse in die werklikheid en visioene wat hy in hallusinasies of drome gesien het, oortuig dat die droom hom sou toelaat om weer met sy geliefde (wat eintlik 'n substituut vir sy eie moeder was) kontak te maak. Gedurende daardie periode van sy lewe is Nerval inderdaad twee keer in 'n psigiatriese kliniek opgeneem weens ernstige geestesversteuring. Die feit van die herhaling dui daarop dat die aantrekkingskrag van die droom te sterk was; tog het Nerval onderneem om in hierdie verhaal so duidelik as moontlik sy eie geval te beskryf en sodoende ander mense te help.

Allereers moet daarop gewys word dat die ooreenkomste tussen droom en werklikheid inderdaad fassinerend is. Die droomvisioene van Nerval vertoon ook indrukwekkende en sprekende ooreenkomste met visioene wat in esoteriese tekste beskryf word: hulle is inderdaad van genealogiese en kosmogoniese aard. Tog is dit moeilik om retrospektief vas te stel of die visioene miskien nie net herinneringe is aan esoteriese werke wat Nerval met groot gretigheid gelees het nie. Die belangrikste egter, vanuit ons standpunt, is dié bevinding dat die oorgawe aan die droom nie 'n ontmoeting met die ander toelaat nie en 
dat die digter onherroeplik in eensaamheid versink. Vir die leser egter is dit duidelik ca: Nerval insig sou gekry het in 'n moontlike oplossing.

Gedurende Nerval se tweede verblyf in die psigiatriese kliniek (hy vertel daarvan is. "Aurélia" Nerval, 413) het sy geneesheer Nerval gevra om 'n medepasiënt te versor: Hierdie pasiënt was 'n soldaat wat uit Afrika teruggekom het en homself volledig atgesıu: het van die wêreld: hy wou nie sien of hoor nie, ook nie eet of drink nie. Nerval het sleg langs hom gaan sit met die kop van die ander sieke op sy skouer en vir hom liedjies uit s? eie kinderjare gesing. Hierdeur het die onmoontlike gebeur: die soldaat het sy oë oopgemaak en begin homself weer oop te maak vir die wêreld. Hier het ons die sleute! tot die simbolistiese werklikheidsbenadering: caritas. Hierdie Latynse term word in Afrikaans deur die woord naasteliefde vertaal - tog gee hierdie vertaling nie heeltemal weer wai in hierdie geval belangrik is nie. Caritas is afgelei van die adjektief carus wat lief, dicriaar beteken, maar in die caritas hoor 'n mens ook 'n paronomase wat carus met caro (vleis) verbind. Hierdie afleiding is nie etimologies van aard nie maar myns insiens 'n soor: taalwenk om die nosie van medemenslike liefde met 'vleislikheid' te verbind, nie as $r$ erotiese verband nie maar wel as die basis vir meegevoel, medelye en die moontlikheid om inderdaad en werklik saam te wees.

Uit dié voorval in Nerval se lewe word iets wesenliks duidelik: die enigste manier om ui: die kringloop van die droom te breek is daardie caritas wat bestaan uit 'n meegevoel wa: konkreet in die liggaam gevoel word en dus nie 'n onwerklike hersenskim is nie. Binne die konteks van die verdere betoog word die term caritas verstaan as hierdie meegevoel en. kommer wat in ons liggaamlikheid gewortel is en ons toelaat om met 'n ander se lot te vereenselwig, nie net in die verbeelding nie maar daadwerklik. Dit is ook opvallend dat dit juis die kinderliedjies was wat in hierdie geval die beslissende deurbraak gemaak net. Nerval sou dit geweet het, want tydens sy eerste krisis is hy in 'n bewustelose toestand in in polisiesel opgesluit saam met ' $n$ jong man wat hom moes oppas en Nerval het sy beuussvn herwin op dié moment toe sy bewaker kinderliedjies begin sing het.

Vir ons moderne lesers is dit 'n ooreenkoms waarvan die waarde moeilik oorskat kan word: die sleutel om die innerlike droomwêreld weer oop te sluit, lê. myns insiens, moontlik in die kinderjare en meer spesifiek in musiek en sang. Is dit nie juis een van die essensiële elemente van liriese poësie nie naamlik dat die verbintenis tussen woord en melodie reg van die begin af 'n skeppende rol speel in die individuasieproses. In sy stem, soos dit in die verrukking van die sang tot harmonie met ander saamsmelt, vind die mens sy ware self en hoogste eenheid met ander. In kinderliedjies is sang nie net individueel en isolerend nie: sang gee ook aan die kind 'n plek in die gemeenskap en in die familie- en volkstradisie.

Nerval het egter steeds bly dink dat hy self 'n soort vat was waarin die esoteriese wysheid van die hele mensheid weer in visioene tot lewe kom, maar daardeur het hy in isolasie ten gronde gegaan: skaars twee maande na die voltooiing van "Aurélia" het hy selfmoord gepleeg. Dat openbaringe oor die ware werklikheid in die oniriese wêreld opgesluit sou lè. is ' $n$ idee wat later deur die Surrealiste opgeneem is. Breton ${ }^{6}$ onder andere het ook die oniriese belewenis gebruik en die spel van objektiewe toeval gespeel om toenadering tor $\mathrm{r}$ vrou te kry, hoewel die droomwêreld gewoonlik 'n isolerende effek het. Dit is bekenó dat

6 Breton verhaal daardie poging in Nadja. Kyk Breton ( $1(\mathcal{K}, 4)$. 
die Surrealiste, toe hulle 'n naam vir hulle groep gesoek het, eers aan die term supernaturalisme gedink het, 'n term wat Nerval in sy voorwoord tot Les filles $d u$ feu gebruik om daardie oniriese openbaringe aan te dui (Nerval, 1974:158). 'n Opvallende trek van die Surrealisme is die byna skisofreniese kombinasie van oniriese toegang tot ander in die erotiek, tesame met 'n Marxistiese betrokkenheid by 'n klasseoorlog. Nerval se digterlike lotsbestemming toon egter duidelik dat die sleutel tot die eenheid met ander nie 'n droom is nie en ook nie 'n militante aksie nie, maar die caritas, 'n meegevoel wat sy oorsprong het in die liggaamlike saamwees van een mens met 'n ander. Daar is ook 'n negatiewe bevestiging van my interpretasie in die feit dat Nerval in "Aurélia" voortdurend uitdrukking gee aan 'n geheimsinnige skuldgevoel wat hom nie verlaat in die periodes waarin hy homself aan die droom uitlewer nie. Hierdie skuldgevoel verbind hyself met die insig dat sy belangstelling vir ander esoteriese godsdienste hom verwyder van die Christelike godsdiens waarvan die caritas één van die sentrale begrippe is. In die lig van Nerval se ervaring sou gesé kon word dat die oorbeklemtoning van die droom, die oorskatting daarvan as middel om 'n verlore eenheid te herstel, 'n beslissende kenmerk van die simbolistiese poëtiek is. Die genese van Nerval se werk en die aanwesigheid daarvan in die hedendaagse digkuns maak egter juis die ruimte oop waarin die ware aard van die oniriese in sy simboliese funksie weer krities oordink kan word.

\subsection{Baudelaire}

Gedurende die laaste twee jaar van sy lewe het Baudelaire vertwyfeld probeer om sy eie skryfwerk winsgewend te maak en sodoende te beantwoord aan die beeld van 'n suksesvolle skrywer soos sy moeder dit altyd van hom verwag het. Hy het selfs aanvaar dat Ancelle. wat as voog vir sy finansiële sake verantwoordelik was, ook as literêre agent vir hom sou optree. Ancelle het, van sy kant af, probeer om homself met die moderne digkuns vertroud te maak. In dié verband het ons 'n brief van Baudelaire aan sy ouer raadsman waarin die digter' $n$ soort geloofsbelydenis aflê:

\footnotetext{
Jy was so kinderagtig om te vergeel dat Frankryk digkuns verafsku, ware digkuns verafsku; dat Frankryk slegs hou vän smeerlappe soos Béranger en Musset; dat iemand wat korrek spel, deurgaan as $n$ mens sonder hart (wat trouens logies is, want die hartstog druk homself altvd sleg uit); ten siotte, dat $n$ digkuns wat diep maar ingewikkeld is, en bitter koud diabolies (oënskynlik), minder byval sal vind by die ewige ligsinnigheid as enige ander digkuns!
}

Moet eik dil vir jou sê, vir jou wat dit net so min as die ander vermoed het, dat ek in hierdie boek, my hele hart, al my teerheid, my hele godsdiens (vermom), al my haat gesit het?

Dis waar dat ek die teenoorgestelde sal skryf, dat ek by God sal sweer dat dit 'n boek van suiwer kuns is, van apestreke, van speelsheid; en sodoende sal ek lieg soos 'n tandetrekker. (Baudelaire, Corr II, 610.)

Hierdie brief is nie sonder ooreenkoms met die brief van Rimbaud wat ons later sal bespreek nie. Baudelaire neem in hierdie brief stelling in teen die letterkunde van sy tyd, maar die belangrikste bly die bewering dat sy bundel Les fleurs du mal'n boek is waaraan hy sy hele lewe gewy het en dat dit nie 'n suiwer kunswerk is nie. Die inhoud van die brief suggereer dat die diaboliese van sy boek slegs skyn is - die leser moet dus begryp dat die digkuns ten nouste met die lewe van die digter verbind is. Weer eens is dit duidelik dat die onderwerp van Baudelaire se denke nie die digkuns self was nie, maar dat hy wel die verband tussen digkuns en bestaan ondersoek het. Daarom ook is Baudelaire se simbo- 
liese denke nie net teorie nie, maar 'n voortdurende bekommernis oor die betekenis van die mens se plek in die universum. Baudelaire het voortdurend die dubbelsinnigheid van simbole belewe: die verbeeldingswêreld self is onwerklik en hy het gedink dat dit gekompenseer word deur die lyding.

Talle van sy gedigte, veral die siklus liefdesgedigte, getuig daarvan dat Baudelaire probeer het om die eenheid met ander te herstel, sonder sukses egter, omdat die beeld en die droom nie 'n direkte verhouding toelaat nie. Die erotiese verlange maak 'n ontmoeting onmoontlik. Slegs in 'n gedig soos "Le balcon", of in fragmente uit sy outobiografiese geskrifte is daar aanduidings van ware gemeenskap met ander. Op die ou end is die verbeelding self ' $n$ krag van die kwaad omdat dit dinge en persone onwerklik maak. Alhoewel hierdie insig slegs geleidelik vorm en gestalte gekry het in sy werk, kan daar tog, reg van die begin af reeds, in die programmatiese sonnet "Correspondances" wat altyd as ' $n$ soort manifes van die simbolistiese skool beskou is, 'n duidelike onrus gevoel word. 'n Aarseling is reeds duidelik in die eerste kwatryn en in die enjambemente in die derde en vierde verse:

\section{La Nature est un temple où de vivants piliers Laissent parfois sortir de confuses paroles \\ L'homme y passe à travers des forêts de symboles \\ Qui l'observent avec des regards familiers. (Baudelairc, 1951:85.)}

Baudelaire erken dikwels dat die beeld ' $n$ illusie is wat in die plek van die werklikheid gestel kan word. Om dié waanbeeld willens en wetens te aanvaar, is één van die kardinale sondes. Daarom is so min van Baudelaire se gedigte formeel volmaak: die gemeenplase en ritmiese onreëlmatighede in die gedigte laat'n gevoel van kommer, angs en vertwyfeling duidelik word. Baudelaire ontwaak altyd uit die droom, soos in die tweede gedeelte van "Rêve parisien": tyd bly die onoorwinbare vyand (Baudeiaire, 1951:170-172): al wat help is liggaamlike aanwesigheid, nie in erotiese ekstase nie, maar in broederlike vriendskap. Daarom rig Baudelaire homself in die openingsgedig tot die leser asof dit sy broer is (Baudelaire, 1951:80). Les fleurs du mal vergestalt die lotsbestemming van 'n menslike gees, 'n gees wat amper nie die verlokkingskrag van die droom soos dit in skone kunswerke verewig blyk te wees, kon weerstaan nie.

Dat 'n gedig inderdaad inkarnasie kan wees, stel die digter baie duidelik in die voorwoord tot Les fleurs du mal wat postuum gepubliseer is (Baudelaire, 1951:1362-66). Hy praat daarin van 'die diepe Franse prosodie': rym en ritme beantwoord aan die diep menslike verlange na monotonie, harmonie en verrassing; die konfigurasie van sinne beantwoord presies aan die ervaring of gemoedstemming wat daarin uitgedruk word. In die eerste weergawe van die voorwoord haal hy die Latynse sin aan: "Et verbum caro factum est" (Baudelaire, 1951:1362): die prosodie wortel in die menslike siel. Weliswaar is die verbeelding die sentrale krag van die siel wat toelaat dat die eenheid van die universum weer simbolies bereik word en ook die innerlike eenheid van die persoon verseker (ooreenkoms tussen gees en liggaam, kontinuiteit tussen verskillende vlakke van die bewussyn). Omdat dit egter buitetydelik werksaam is, word dit ook 'n derealiserende krag wat die mens sy tydelikheid en eindigheid laat vergeet. In die vergetelheid van die droom is die mens eensaam en verlate, onder die indruk dat hy toevlug in ' $n$ paradys gevind het. Net soos by Nerval, het die aantrekkingskrag van die droom ook in Baudelaire se lotsbestemming ' $n$ beslissende rol gespeel omdat dit 'n ware verhouding met ander amper 
onmoontlik gemaak het. Terselfdertyd is Baudelaire se poëtiek steeds werksaam in dié sin dat dit die spanning tussen droom en handeling met 'n soms tragiese helderheid van gees bly beleef; vandaar die soms skerp sarkasme en deurlopende bitter ironie. Baudelaire se Les fleurs du mal bly nog altyd die oorsprong van die moderne Franse digkuns omdat dit die vraag stel omtrent die moontlike rol wat die digkuns in menswording kan speel. Daarom moet ook in gedagte gehou word dat Les fleurs du mal verskyn gedurende 'n tydstip in die geskiedenis waarop die industrialisasie en die ontgeesteliking van die wêreld en van die gemeenskap sy eerste duidelike spore begin laat het.

En tog, alhoewel die digter gevaar loop om in die onwerklike beeld van die droom op te gaan, bly dit nog altyd sy opdrag om die mense aan hulle geestelike roeping te herinner. Dié geestelike roeping is veral dié van broederlikheid, van naasteliefde, van caritas: die ontmoeting met ander. Veral in die "Tableaux parisiens" word die tema van die ontmoeting op ' $n$ indrukwekkende manier verwoord, 'n ontmoeting wat dikwels toevallig is. Baudelaire se poëtiek hou nog rekening met die toeval, iets wat Mallarmé vertwyfeld en tevergeefs uit sy beplande boek probeer uitsluit het.

Steeds aanwesig in die hedendaagse digkuns dan, is Baudelaire se konsep van moderniteit: die vlugtige momentele ontmoeting wat in die onbeweeglike vorme van 'n kunswerk verstar; die hier en nou van die ervaring wat gevaar loop om in die strakke ewigheid van die skone op te gaan. Hedendaagse digters dink nog steeds na oor die problematiese eenheid tussen die empiriese sosiale ek van die digter in sy eksistensiële beperkings en die poëtiese ek wat met die hulp van sy verbeelding toegee aan 'n demiurgiese illusie: hierdie teenstrydigheid word opgehef deur die dood wat die einde van alle verbeelding is.

\subsection{Rimbaud}

Baudelaire was vir Rimbaud die vergestalting van 'n eerste siener, koning van die digters, 'n ware god. Dit is die woorde wat hy gebruik in die beroemde brief van $15 \mathrm{Mei} 1971$ aan sy onderwyser Paul Demeny; die brief wat as die 'Brief van die siener' bekend staan (Rimbaud, 1954:169-174). Rimbaud voeg egter onmiddellik beperkende opmerkings daaraan toe: vir hom was Baudelaire te kunsmatig en die vorm by hom nog te bekrompe.

Hierdie 'Brief van die siener' word as vertrekpunt geneem vir 'n ondersoek na Rimbaud se poëtiek. Rimbaud was 17 jaar oud toe hy dié brief geskryf het. Hy was diep getref deur die besef dat sy moeder slegs uit pligsgetrouheid teenoor hom liefde betuig het. ("Les poëtes de sept ans": v. 30. Elle avait le bleu regard, qui ment (Rimbaud, 1954:77)); daarby kom die ontdekking dat poësie weliswaar wonderlik kan wees maar tog net illusies in die plek van die werklikheid plaas (Ce qu'on dit au poète à propos de fleurs (Rimbaud, 1954:95)). In die brief besluit Rimbaud om die digkuns weer outentiek te maak deur die individu, soos die Christendom bely, sistematies af te breek. Sodoende sou hy ontkom aan die dubbele rede vir die afkeer in homself en sal die mens weer in harmonie wees met die dinge en die syn soos by die oorsprong van die skepping. Die lees van esoteriese werke het seker ' $n$ rol in hierdie siening gespeel. Nie alleen moet die mens ter wille van hervereniging met die kosmos afgebreek word nie, maar ook die taal moet van die rasionalistiese keurslyf bevry word sodat die visioene direk en in hulle oorspronklike ritme neergeskryf kan word. Rimbaud het sy program van 'n 'sistematiese versteuring van die sintuie' uitgevoer: hy het 
sy eie siel geweld aangedoen om die buitewêreld meer outentiek in homself aan die lig te laat kom. Op die ou end egter, soos hy dit stel in "Alchimie du verbe" (Rimbaud, 1954:232238) was die hele poging 'n mislukking, omdat dit hom van ander geïsoleer het en omdat die geslaagdheid daarvan altyd voorlopig was, bedrieglik en kunsmatig gebly het. Digkuns verander nie die lewe nie. Die vonk van hierdie siening is gekoppel aan 'n duister ongeluk, want die digter word uit die liefde uitgesluit; daarom word hy uit die menslike gemeenskap verban.

Rimbaud se digterlike avontuur het tog sin gehad, en vir later geslagte bevat dit waardevolle lesse wat miskien nie altyd duidelik verstaan is nie. Dit is ook so dat Rimbaud se werk baie min tekstuele kommentaar uitgelok het, juis omdat hy 'n poëtiek ontwikkel het wat berus op die ware stoflike konkreetheid van die woorde (nie die geëmansipeerde betekenisdraer nie). Op hierdie wyse kom woorde in die bewussyn op in 'n prerefleksiewe kontinuïteit met die dinge soos hulle (om dit 'Heideggeriaans' te stel) in die openheid van die syn sigbaar word.

Rimbaud se poëtiek berus dus op die intuïsie dat dinge ' $n$ taal is wat in die stoflike konkreetheid van woorde, soos hulle in 'n oorspronklike ritme in die bewussyn van die digter opkom, betekenis en sin tot stand bring. Die taalritme kan presies beantwoord aan die ritme van dinge en 'n gedig sê proporsioneel hoe die 'logos' van dinge by 'n mens opgeroep word. Dit is hierdie stoflike konkreetheid van die digterlike taal wat teenswoordig deur teoretici misken word as gevolg van hulle slaafse toepassing van Saussure se basiese hipoteses naamlik die willekeurigheid van die teken en die sistematiese aard van die taal. Dit is veral in die fenomenologie waar Rimbaud se poëtiek nuttig sou kon wees. As verteenwoordiger van die teenswoordige tydvak dink ek natuurlik eerstens aan Heidegger? , en aan Merleau-Ponty met sy studie oor 'die prosa van die wêreld'8 en sy chiasmatiese opvatting van die verband tussen bewussyn en wêreld, en dan aan digterdenkers soos Jacques Garelli, of Michel Deguy.

Maar om terug te kom tot Rimbaud. Ons uitgangspunt was die ontevredenheid van die digter met sy eie bestaan: sy moeder het slegs die uiterlike tekens van geneentheid jeens hom betoon en terselfdertyd het hy die kunsmatigheid van die meeste eietydse gedigte (met die uitsondering van Baudelaire s'n) ervaar. Rimbaud se roeping as digter is onuitwisbaar gekenmerk deur die besef dat woorde en tekens dubbelsinnig is, maar ook deur die wil en hoop dat die woord in die toekoms weer waarheid en die basis vir'n verandering van die lewe sal kan wees. Rimbaud het die grense van die taal met betrekking tot die toekoms ondersoek: die bewussyn van die sistemiese grense van taal kan vrugbaar wees vir sover die sisteem nie absoluut gestel word nie. In dié sin het Rimbaud ook die grense van strukturalistiese taalondersoek aangedui. Daarom ook het die semiologie geen vat aan sy digkuns gekry nie. Dit sou dan die genetiese struktuur van sy werk wees wat nie eindig met Une saison en enfer nie, en die demiurgiese gebruik van beelde wat nie die harde werklikheid kan vasvang nie. Verskeie van sy Illuminations dateer van ná die Saison waarin hy eintlik wou afskeid neem van die digkuns en toon 'n weg aan

\footnotetext{
${ }^{7}$ Heidegger het trouens op 'n stadium belang gestel in Rimbaud se werk, veral die sin "La pocsie ne rythmera plus l'action. Elle sera en avant" en vir die bekende Franse digier René Char gevra om dit te verduidelik. Kyk Char (1983), pp. 734-736.

${ }^{8}$ Kyk Merleau-Ponty (1969) en (1964).
} 
wat wys in die rigting van 'n moontlike oplossing, naamlik die ontsluierende krag van die poëtiese woord wat nuwe aspekte in die werklikheid ontdek danksy die herbeskrywende en vooruitwysende aard van die poëtiese beeld. Hierdie kreatiewe waarde van die beeld is later teoreties ondersoek en begrond deur die digter Pierre Reverdy en kom ook weer ter sprake in die hermeneutiek van Paul Ricoeur. 'n Gedig soos "Aube"(Rimbaud, 1954:194) is 'n soort visie van wat wesenlik en essensieel van die daeraad is. In die Illuminations word dit duidelik hoe 'n wêreld homself ontplooi vir die menslike bewussyn in die konkrete omstandighede van 'n hier en 'n nou sonder om totaal onverstaanbaar tot 'n soort privaattaal verdoem te wees.

Dat Rimbaud 'n totale gebrek aan selfvertroue gehad het, het waarskynlik daartoe gelei dat hy anders as Baudelaire op die werklikheid gereageer het. Hy het nooit 'n periode van ware liefde belewe soos Baudelaire vóór die hertroue van sy moeder nie, en sodoende het Rimbaud nie die ervaring van wedersydse liefde geken nie. Rimbaud se poëtiek wat tog 'n toenadering tot dinge gesoek het, het meer as wat dit by Baudelaire die geval was, berus op die lees van digters en outeurs van esoteriese werke. In Baudelaire se poëtiek is daar plek vir teerheid en respek vir die alledaagse; Rimbaud het 'n totale hernuwing van die lewe nagestreef deur eers die taal te hervorm om dit toe te laat om die werklikheid te omarm.

Vir baie moderne digters het die kennismaking met Rimbaud ' $n$ beslissende wending aan hulle lotsbestemming gegee omdat dit in sy beste gedigte duidelik word hoe die werklikheid in die woorde beproe(f) kan word, nieteenstaande die onvolmaaktheid en begrensdheid van die taal, en dat daar in die toekoms dus tog 'n moontlikheid mag wees om die lewe te verander en om die waarheid na siel en liggaam te besit. Rimbaud was miskien net 'n bietjie te ongeduldig met sy familie. Veral sy moeder het miskien te veel druk op hom uitgeoefen om sosiale sukses na te streef: daarom het Rimbaud op 21-jarige ouderdom opgehou met sy poging om die lewe te verander en besluit om oorsee rykdom te gaan soek.

Die noodsaak om die lewe te verander, het in die geskiedenis van die digkuns van die 20ste eeu 'n groot rol gespeel, veral in verband met rewolusionêre ideologieë. Die Surrealiste het byvoorbeeld die bevryding van die taal gekoppel aan polities-rewolusionêre aktiwiteit. Dit was miskien gedeeltelik 'n kompensasie vir die gebrek aan konkrete werklikheid in hulle outomatiese tekste, en ook vir die speelsheid van hulle skryfaktiwiteit, sowel individueel as kollektief. Rimbaud se woorde, "Je est un autre", het hulle verstaan as 'n uitnodiging tot kollektiewe kreatiwiteit waarin die surrealiteit wat gesoek word opduik as irrealiteit, as 'n uitdrukking van die digter se willekeur in plaas van as 'n ontsluiting van nuwe maar reële aspekte van die wêreld.

\subsection{Mallarmé}

Mallarmé het nooit self sy poëtiek in een enkele teks uiteengesit nie: die bespreking wat volg, berus op uittreksels uit sy talryke briewe aan vriende en digters en op die outobiografie wat hy vir Verlaine se bydrae tot "Les hommes d'aujourd'hui" geskryf het (Mallarmé, 1945:661-665).

Vir Mallarmé kan daar niks aan die wêreld verander word nie: "la Nature a lieu" - die natuur gebeur, en ons kan alleen maar 'n paar stede en spoorweë daaraan toevoeg. Die 
ruimte waarin die mens sy vryheid kan uitoefen is nie dié van die wêreld nie maar dié van die idee. Die mens is slaaf van die dinge waarmee hy wil of moet werk: slaaf as hy werk in n gebied wat nie deur sy eie wil en aktiwiteit ontstaan het nie. Net die kuns beliggaam die soewereiniteit van die mens, van sy heerskappy oor die werklikheid; net die kuns erken slegs homself as wet, is volledig outonoom. Dit is dus nodig om die kuns, in Mallarmé se geval die digkuns, te sujwer. Mallarmé se poëtiek vind sy oorsprong in die besef dat die natuur 'gebeur' en wat in die natuur gebeur is duidelik. Tog, sodra Mallarmé die natuur probeer benader, vervlugtig dit; hy kan nie tot die dinge deurdring nie. Sodoende verander die oorspronklike vertroue in die natuur in angs wat waarskynlik wortel in die jeugervaring van eensaamheid. Hierdie eensaamheid spruit voort uit die gemis aan sy moeder en daarom neem die digter sy toevlug tot die woord. Hierdie simboliese toenadering veroorsaak 'n tweede ontgogeling: woorde is arbitrêr en sê dinge nie soos hulle is nie; woorde is net tekens en nie simbole nie.

Tog ontstaan daar poësie. weliswaar in uitsonderlike gevalle, as 'n gedig aan 'n innerlike noodsaak gehoorsaam is. Op grond hiervan maak Mallarmé twee gevolgtrekkinge: in 'n gedig is dit die vers wat vir die onvolmaaktheid van die woorde kompenseer. Op die vlak van toenadering tot die werklikheid. stel die musikale aard van die vers die suiwer idee soos dit in die menslike bewussyn sy perfekte vorm aanneem in die plek van die ondeurdringbare stoflike konkreetheıd van die dinge. Maar om tot die suiwer idee te kom. los van alle subjektiwiteit, moet die digter eers aan sy eie persoon sterf en opgaan in die suiwer vreugde van 'n spel mel vorme waarmee die toeval geëlimineer sou kon word. Maar selfs 'n werp van die dobbelsteen sal die toeval nooit ongedaan kan maak nie. Taalkombinasies, hoe berekend ook al, is slegs fiksie, 'n leuen. Mallarmé gebruik vir die digkuns meestal die woord droom. Dit mag nie met die nagtelike droom verwar word nie; dié het hy heeltemal verwerp as strydig met die totale helderheid van gees wat nodig is om ' $n$ volmakte gedig te skep. In hierdie droom staan die taal nie meer in verband met die konkrete werklikheid nie; gevolglik eis die droom die verdwyning (of die dood) van die digter. Tog was Mallarmé terdeë daarvan bewus dat hierdie absolute outonomie van die droom (die absolute skoonheid en sy taal) in illusie is omdat die taal nooit die werklikheid sal kan weergee nie. Ontologies is die taal onbruikbaar en die menslike subjektiwiteit moet verdwyn ten gunste van $n$ suiwer idee.

Hierdie twee voorvereistes val histories saam met die God-is-dood-teorie soos Nietzsche dit aangekondig het. In die plek van die teologie van die woord, stel Mallarmé dan die ryk van die letter of, in meer hedendaagse terme, die regime van die teken of van die betekenisdraer. In die moderne teorie, veral by Maurice Blanchot, is hierdie siening van Mallarmé letterlik opgeneem en tot sy laaste, absurde konsekwensies deurgetrek. Deur die kommentaar van Blanchot in samewerking met die stellinge van die tekstualisme te bestudeer, wil dit lyk asof dit Mallarmé se werk is wat, kwalitatief altans, die meeste invloed in die literêre teorie uitoefen.

Dit is die moeite werd om Blanchot (1955 en 1959) se interpretasie van Mallarmé te oordink: daarmee het ons dan ook in die hedendaagse modernisme beland. Blanchot lig dié elemente in Mallarmé se geskrifte uit wat in die rigting van 'n onmoontlike maar suiwer idee van literatuur wys. Om te skryf, of om soos Mallarmé dit stel. 'n vers te ontgin (letterlik uit te grawe: creuser), stel die digter voor 'n dubbele afgrond: die leegte, soos dit ervaar word in die afwesigheid van God, en sy eie dood, soos hy dit voel in die 
siekteverskynsels wat sy denkpogings begelei. Mallarmé het inderdaad gesterf as gevolg van asemnood omdat hy nie 'n woord kon artikuleer nie. Om verse te skryf, beteken om afwesig te wees, ver van die waarheid en van die syn af, in die aangesig van jou eie dood. Die taal self is eintlik 'n manier om stil te bly, om niks te sê nie: woorde van die normale taalgebruik is onmiddellik en brutaal, onwesenlik, en die wesenlike of poëtiese spraak is onwerklik, taal van afwesigheid. Hierdie afwesigheid van die wêreld in die poëtiese taal noem Mallarmé 'fiksie', ruimte waarin die dinge nie in hulle aanwesigheid kan verskyn nie. Gewone taal is illusie omdat dit die 'gewone' of aanvaarde visie op dinge weergee. Sodoende kan ware spraak slegs plaasvind as die konkrete dinge afwesig is. Die digterlike wêreld is nie meer die ruimte waarin die mens doelwitte nastreef en sy eie bestaan sinvol uitbou nie, dit is nie meer 'n woning of 'n tuiste nie: dit is die suiwer wêreld van afwesigheid in die denke. Die suiwer taal is onpersoonlik, die digterlike taal lê dinge die stilswye op en dit is die einde van die simboliese denke. Die taal praat nou self, nie van iets nie; die taal manifesteer niks en druk ook nie die spreker se gedagte uit nie. 'n Gedig is dan volgens Blanchot net 'n objek wat uit woorde 'gefabriseer' is en digkuns is dan net besinning oor sy eie essensie. Die wêreld verdwyn in die essensiële taalnet en die subjek sterf in die skryfdaad. Om te skrywe is 'n daad van selfdestruksie, 'n soort selfmoord. Die digter bevind hom in 'n onmoontlike teenspraak: aan die een kant die materiële wêreld van dinge, 'n reële wêreld waarin dinge per toeval kombineer maar sonder die tussenkoms van die subjek; aan die ander kant is daar 'n valse, leuenagtige wêreld (ons mag nooit vergeet dat Mallarmé self die droom of die poëtiese wêreld as 'n leuen erken het maar dit tog willens en wetens gekies het) waarvan die bekoring die digter verlam. Die digter is tussen die toeval en die leegte: die enigste uitweg is die dood. In Mallarmé se oeuvre was dit slegs 'n filosofiese dood.

Onder die hedendaagse digters het Bonnefoy die genese van Mallarmé se poëtikale besinning besonder goed verstaan en hy stel die aanvaarding van die toeval, waardeur die ontmoeting met die ander weer moontlik word, voor as oplossing. Vir Blanchot egter is die poësie onmoontlik omdat dit vergeefs sy eie oorsprong naspoor om dit teenwoordig te maak. Dan bly slegs die woord "c'est", dit is, nog voordat iets is, nog voordat 'n subjek gekies het wat dit sal wees en hóé dit sal wees, nog voordat inkarnasie plaasvind en vorm homself uitbrei in die tydsruimte. Dit is dan ook logies dat Mallarmé sy 'boek' slegs kon beplan: daar is nie meer 'werke' nie, slegs nog planne, met ander woorde: wanneer die digkuns na sy eie wese gaan soek, word dit self onmoontlik. Die moderne digters is, volgens Blanchot, in hierdie verlammende situasie opgesluit. Mallarmé is die eerste, profetiese voorbeeld daarvan. Letterkunde is die domein van die suiwer virtualiteit: die digter verdwyn agter die boek en van die boek bly slegs 'n plan oor. Die waarneembare wêreld word verwerp ten gunste van die idee, die dinge verdwyn in die sentrale leegte van die verbande tussen hulle soos dit in die literêre beelde gefikseer word. In die teks is daar slegs verhoudings tussen woorde, weerspieëling van klanke, wederkerigheid: die aspekte keer weer en wissel plek sodat die substansie verdwyn.

Tog is dit moontlik om Mallarmé se poëtiek positief te waardeer en talle digters het die uitdaging wat in Mallarmé se poëtiek verwoord is, aanvaar, byvoorbeeld in verband met die vers en verseenheid. In plaas daarvan om 'n suiwer idee te wil verwoord, kan die digter die vers ook as 'n konkrete eenheid van die veelheid in sy harmonie betrag; ' $n$ wêreld kan tot stand kom in die harmonie van die vers of van die strofe, nié omdat die toeval uitgeskakel word nie, maar juis omdat die toeval toegang gee tot die werklikheid, daar waar die droom 
'n onwerklike uitdrukking is van die onrealistiese verlangens van die subjek.

In die versvorm ontstaan 'n ruimte waarin die versugtinge van die mens na harmonie (vg!. Baudelaire, 1951:1363) getoets kan word aan die naakte werklikheid van wat konkreet in die wêreld aanwesig is. As vorm staan die vers in spanning met sy eie ontstaan en wat buite sy grense aanwesig bly. Die vers is nie noodsaaklikerwys die gevormde vorm waarin die formele verbande tussen woorde duidelik is nie: dan het die onbewuste vrye spel. Maar, sodra die vers bewus word van sy eie grense en sodoende 'n oop ruimte word, dan is daar die moontlikheid van genese, wording, en dan kan die lewe inderdaad verander word. Mallarmé was miskien die eerste digter wat oor die wese van die vers nagedink het. Hy was ook ontsteld dat sy tydgenote vrye verse begin skryf het ("on a touché au vers") (Mallarmé, 1945:360). Dit is egter nie nodig om sy oordeel te aanvaar nie. Die vers is nie noodsaaklikerwyse 'n manier om die toeval uit te skakel nie, maar dit kan 'n ruimte skep waarin ontmoeting kan plaasvind.

\section{Die moderne digkuns}

$\mathrm{Na}$ dié vier groot Simboliste ontwikkel die digkuns in 'n spanningsveld wat deur hulle geopen en afgebaken is. Die digter staan as persoon in die spanningsveld tussen die empiriese ek wat sterflik is in sy begrensde bestaan en die ouktoriale ek, 'n soort demiurg wat sy verbeeldingskrag die vrye loop laat neem in 'n gedig. So is die digter voortdurend on soek na ' $n$ amper onmoontlike saamval van die poëtiese mag (wat slegs oneindig is $\mathrm{m}$ die wêreld van beelde) met die eksistensiële ek. In sy verhouding tot die wêreid en die eietydse gebeure, staan die digter voor die alternatief om die droom van die aksie te skei: vandaar die vraag na sy sosiale relevansie. Hierdie spanningsveld word ondersoek en in stand gehou in en deur die taal waarvan die ontologiese waarde bevraagteken word deur die dubbelsinnigheid van alle tekens. Tog het die groot Simboliste 'n oplossing voorberei wat myns insiens geleë is in die cartas, die naasteliefde. dié begrip in al sy betekenisse. Fiksie is 'n virtuele wêreld wat aktueel kan word in die interpretasieproses wat ook n toepassing insluit. In die mate wat digkuns 'n ruimte oopmaak waarin ware ontmoeting kan plaasvind en waar die verlore eenheid herstel kan word, het dit "n belangrike rol te speel in die uitbouing van 'n egte menslike gemeenskap.

Miskien kan daar 'n verskil gemaak word tussen enersyds die digters wat genoeë neem me: die woorde en as bewys van hulle eie lewe 'n kunswerk wil agterlaat, en andersyds daardie digters wat op 'n ander manier vir die toekoms werk. Laasgenoemde groep verteenwoordig dié wat die grense van 'n taal ondersoek om dit te oorskry, dié wat met behulp van die taal die lewe wil verander - nie as propagandiste of spreekbuise vir politieke partye of ideologièë nie, maar as ontdekkingsreisigers in die tot nou toe nog onontginde gebiede van die menslike gees, waar toenadering en versoening moontlik word in die universele, waar die onderskeid slegs getref word ter wille van 'n diepere eenheid.

\section{Bibliografie}

Baudelaire, C. 1951. Oeuvres. Bibliothèque de la Pléiade. Paris: Gallimard.

Baudelaire, C. 1970. Correspondance. Bibliothcque de la Pléiade. Paris : Gallimard. 
Blanchot, M. 1955. Approche de l'espace littéraire. L'espace Littéroire Coll. Idées. Paris : Gallimard. pp. 29-48.

Blanchot, M. 1959. Le livre à venir. Le livre duenir. Coll. Idées. Paris : Gallimard. pp. 326-358.

Breton, A. 1964. Nadja. Paris: Gallimard.

Char, R. 1983. Oeuvres complètes. Bibliothèque de la Pléiade. Paris : Gallimard.

Mallarmé, S. 1945. Oeuvres complètes. Bibliothèque de la Pléiade. Paris : Gallimard.

Merleau-Ponty, M. 1964. Le visible et l'invisible. Paris : Gallimard.

Merleau-Ponty, M. 1969. Une prose du monde. Paris: Gallimard.

Nerval, G. de 1974. Oeuvres I. Bibliothèque de la Pléiade. Paris : Gallimard.

Rimbaud, A. 1954. Oeuvres completes. Bibliothèque de la Pléiade. Paris : Gallimard.

Rombach, H. 1971. Strukturontologie. München: Alber.

Rombach, H. 1981. Substanz System Sinktur. München : Alber.

Wellek, R. 1970. The Term and Concept of Symbolism in Literary History. Discriminations. London : Yale University Press.

Winnicott, D. 1971. Playing and Reality. London : Tavistock.

\section{Universiteit van Pretoria}

